\title{
Hodnocení kvality terénních programů digitální interpretace př́rodního dědictví
}

\author{
Jan Činčera, Michal Medek, Miroslav Lupač
}

Envigogika 13 (1) - Recenzované články/ Reviewed articles

Publikováno / Published 5. 4. 2018

DOI: $10.14712 / 18023061.560$

\section{Abstrakt}

Studie diskutuje otázku kvality terénní digitální interpretace př́rodního dědictví. Popisuje proces vymezení kategorií kvality, který zahrnoval kombinaci literární rešerše, diskuse $\mathrm{s}$ experty $\mathrm{v}$ rámci ohniskové skupiny a terénní průzkum. $\mathrm{V}$ poslední části představuje a diskutuje klíčové kategorie kvality, které by se mohly stát doporučením pro další autory digitální interpretace.

\section{Klíčová slova}

Interpretace prírodního bohatství; digitalizace; evaluace; kvalita

\begin{abstract}
The study discusses the question of quality of field digital interpretation of natural heritage. It describes the process of defining the quality criteria, encompassing a combination of literature review, focus groups with experts, and field survey. In the last part it introduces and discusses the key quality criteria for recommendation for futher authors of digital interpretation.
\end{abstract}

\section{Key words}

Interpretation of natural heritage; digitalisation; evaluation; quality 


\section{Úvod}

Rozšíření "chytrých" mobilních telefonů i rostoucí zvyšování kvality pokrytí České republiky signálem otevírá možnost využití digitálních technologií pro terénní interpretaci přírodního dědictví. Poměrně běžně se tak můžeme setkat např. s propojením informační tabule či panelu naučné stezky s digitálním obsahem pomocí QR kódu či jiného technického řešení. Systém taggmanager, představující jeden s nejrozšířenějších systémů pro zpracovávání naučných stezek do prostředí mobilních telefonů, $v$ současné době eviduje 378 stezek se zpracovanou mobilní aplikací (Taggmanager.cz, 2017). Svoji digitální vrstvu ale mají i informační panely maloplošných př́rodních rezervací. Jiným príkladem mohou být speciální aplikace zpracované $v$ režimu rozšířené reality (AR) distribuované prostřednictvím obchodů pro mobilní aplikace.

Oblast digitální interpretace, tj. takové formy nepřímé interpretace přírodního dědictví, která při interakci s návštěvníky z části či zcela využívá podporu digitálních médií, současně otevírá otázky kvality zpracování. To s sebou přináší specifické obtíže. Oblast digitální intepretace je nesmírně různorodá a to jak z hlediska účelu (znalosti versus zážitek), cílů vzdělávání (ve formální versus informální oblasti) či technického řešení. Kritéria kvality, publikovaná v různých studiích, proto odrážejí různé aspekty digitální interpretace a nelze je použít pro všechny případy.

Cílem této studie je předložit k diskusi návrh na vymezení kritérií kvalitní digitální interpretace prírodního dědictví. Návrh čerpá z existující literatury, názorů domácích expertů a zkušenosti s terénním výzkumem digitální interpretace.

V první části se zaměříme na proces vzniku kvalitativních kritérií pro terénní digitální interpretaci v domácím kontextu. Ve druhé pak budeme diskutovat konkrétní návrh, vytvořený na základě analýzy zahraniční literatury i rozhovorů s domácími experty.

\section{Přehled literatury}

Terénní digitální interpretace přírodního dědictví není, na rozdíl od interpretace kulturního dědictví, v odborné literatuře dosud př́liš diskutována. Problematice její kvality se věnuje pouze několik studií.

V obecné rovině se aplikací technologií pro interpretaci zabývali Beck a Cable (2011), kteří vyčlenili tři znaky dobrého použití technologií v interpretaci:

1. Technologie musí být poutavá, především interaktivitou, nikoliv však pouze zábavná, protože hrozí, že by zábava rozptylovala pozornost uživatelů od smysluplných zážitků. $\mathrm{K}$ nežádoucí frustraci může dojít též vlivem složitého ovládání.

2. Technologie musí být spolehlivá a při jejím pořizování se musí brát v úvahu náklady na její dlouhodobou údržbu.

3. Technologie by měla otevírat nové úhly pohledu, tzn. především rozšiřovat smyslové možnosti uživatele.

Spíše technická řešení pro outdoorové mobilní aplikace navrhují Walmsley a Crowe (2016). Podle jejich výzkumu jsou klíčovými aspekty pro využití aplikace návštěvníkem pocitóovaná snadnost jejího užívání, pocitóovaná užitečnost a zábava. Aplikace by proto měly 
podle nich určitě obsahovat mapy s možností zoomování, fotografie z lokalit a možnost vkládat vlastní fotografie, opakovací kvízy. Použití by mělo předpokládat rychlou odezvu, možnost opravovat obsah, širokou dostupnost a malé nároky na případnou další infrastrukturu.

K trochu jiným výsledkům došli Shin, Jung a Chan (2012), kteří zkoumali faktory, vedoucí spotřebitele $\mathrm{k}$ použití QR kódů. Hlavní roli podle jejich výzkumu hraje očekávaná interaktivita (možnost kontroly nad ovládáním, konektivita a responzivita), dále pak subjektivní normy. $\mathrm{V}$ menší míře předpokládaná kvalita obsahu a systému.

Pendit, Zaibon a Bakar (2014) zkoumali kritéria pro kvalitní využití rozšířené reality (augmented reality, AR) v kulturní interpretaci. $V$ jejich studii je předpokladem efektivního učení plná pozornost (mindfulness) uživatelů. $K$ té dochází při správné kombinaci vnějších faktorů komunikace (různost a změna, multismyslová média, novost/konflikt/překvapení, otázky, interaktivita a možnost kontroly, propojení s návštěvníkem, dobrá fyzická orientace) s personálními faktory návštěvníka (zájem o obsah, malá hladina únavy). AR aplikace by proto měly dávat uživateli kontrolu nad průběhem interakce (např. volbou různých modů zobrazení atd.), měly by nabídnout široké spektrum použitých médií (text, obrázky, dokumenty, video atd.), změny perspektivy a další možnosti pro posílení pocitu překvapení a novosti, a také dobrou fyzickou orientaci (mapu). Měly by dále uživatelům klást otázky a zapojovat je do vzájemné interakce, aby tak posilovaly sociální kohezi a s ní související radost $z$ interakce s aplikací. Podobná kritéria pro AR aplikace doporučují Liarokapis, Sylaiou a Mountain (2008). Podle nich by aplikace měla nabízet více vrstev obsahu, umožňující různé druhy interakce, měly by mít snadné ovládání a měly by podporovat aktivní učení. To by mělo být podporováno i zábavou. Autoři by se měli vyhnout dlouhým textům rušícím návštěvnický zážitek.

V této souvislosti navrhují Zimmerman a Land (2014) zásady pro zpracování mobilních aplikací podporujících místně zakotvené učení. Podle nich by aplikace měla:

1. podpořit zapojení studentů do odborné diskuse tím, že poskytne konceptuální organizaci základních charakteristik místa a propojí předpokládané znalosti studentů s novými poznatky;

2. rozširíit poznání o relevantní aspekty místa, tj. upoutat pozornost studentů a soustředit ji na specifické rysy místa či objektu, doplnit o kontextuální informace týkající se místa či objektu;

3. propojovat místní zkušenosti s obecnějšími pomocí otevření nových perspektiv, tj. upozornit na objekty související se sdělovanými myšlenkami a na neviditelné aspekty místa, a to pomocí AR; dále by měla nabídnout možnost sběru a sdílení dat.

Přes značné rozdíly se zdá, že je možné kritéria kvality digitální interpretace uváděné jednotlivými autory rozdělit do několika skupin. Digitální interpretace by měla být především dobrou interpretací, a $\mathrm{k}$ tomu by měla respektovat tematický př́stup, dobře organizovat samotné sdělení, propojovat téma i lokalitu s návštěvníkem. Měla by být uživatelsky příjemná, snadná na ovládání, zábavná, technicky nenáročná a nezahlcující. Měla by podporovat interakci návštěvníka s obsahem, tj., zejména mu dávat možnost volby, spoluvytváření obsahu a sdílení s dalšími uživateli; důležitou roli může hrát i určitá gamifikace (tj. podpora učení prostřednictvím hry), která ovšem nesmí být na úkor přímého zážitku s interpretovaným objektem. $V$ neposlední řadě by měla $v$ oprávněné míře využívat možností média $k$ prezentaci takového obsahu, který bude zajímavý a motivující - např. využivat multimediálnost, nabízet více datových vrstev, praktické informace jako je mapa a další. 


\section{Proces vymezování kritérií kvality}

V praktické rovině byl proces definování kritérií kvality terénní digitální interpretace přírodního dědictví zahájen v únoru 2017 v rámci společného projektu Masarykovy univerzity Brno a neziskových organizací BEZK a Agentura Koniklec. Odborný tým odpovědný za zpracování prvního návrhu byl složený ze spoluautorů tohoto textu. V jeho rámci vznikl v květnu 2017 první návrh (viz Příloha 1), který byl dále distribuován domácím expertům (viz Př́loha 2) v oblasti interpretace, kteří byli současně pozvání na ohniskovou skupinu, která měla návrh diskutovat.

Respondenti byli předem seznámeni s pracovním návrhem kritérií pro kvalitní digitální interpretaci a na místě ( $v$ některých případech i v navazující e-mailové korespondenci) se k nim vyjadřovali. Ohnisková skupina byla současně nahrávána, nahrávka pak byla přepsána a využita pro analýzu názorů respondentů na možnosti a kvalitu digitální interpretace. Ohniskové skupiny se zúčastnilo celkem 11 expertů (ze kterých dva byli současně spoluautoři této studie), diskuse byla přibližně dvě a půl hodiny dlouhá.

Názory domácích expertů na kritéria kvality digitální interpretace se ve většině sledovaných otázek lišily. Vysoká shoda panovala v tom, že hodnocení kvality digitální interpretace je obtižné a že žádná kritéria by proto neměla být chápána jako závazná a vyžadovaná. Experti dále poukazovali na to, že kvalita je obtížně kvantifikovatelná a případné hodnocení by proto spíše nemělo jít cestou „bodování".

Experti se často vyjadřovali ke smyslu digitální interpretace skepticky, respektive jejich názory pokrývaly široké spektrum od víry v její možnosti až po zpochybnění jejího potenciálu vůbec. Podle jednoho z expertů je digitální interpretace výsledkem trendu "konzumace divočiny". Podle dalších skeptických názorů je to spíše hračka, která se používá pro svoji novost, než kvůli možnostem uplatnění. Experti dále upozorňovali na technické bariéry, související s rychlostí připojení, i na nedostatky v provedení digitální interpretace.

Neshody se objevily v otázce vhodné cílové skupiny tohoto typu interpretace či v důležitosti jejího zaměření na širokou či specificky vymezenou veřejnost. Sporným bodem také bylo, zda a jakým způsobem má digitální interpretace podporovat komunikaci návštěvníků s jinými uživateli.

Celkově Ize shrnout, že názory domácích expertů na digitální interpretaci byly převážně skeptické a v pohledu na kritéria její kvality se spíše rozcházely.

Na základě vyhodnocení dat z ohniskové skupiny byl zahájen proces mapování a hodnocení případů terénní digitální interpretace přírodního dědictví. Ten proběhl v období květen-září 2017. V jeho rámci autoři navštívili několik chráněných přírodních lokalit v České republice a z návštěvnické perspektivy ověřovali stav tamější digitální interpretace. Všechny nalezené případy byly zdokumentovány. Celkově byly takto posuzovány následující lokality:

- CHKO a Geopark Český ráj (prozkoumáno sedm případů digitální interpretace),

- CHKO Moravský kras (čtyři případy)

- $\quad$ CHKO Český kras (dva prípady)

- Hlavní město Praha (čtyři případy)

- $\quad$ CHKO Jizerské hory (čtyři případy) 
- Př́rodní park Podještědí (jeden případ)

- CHKO Bílé Karpaty (celkem čtyři prípady)

- Krkonošský národní park (sedm případů).

Navíc bylo vyhodnoceno šest aplikací pokrývajících celou Českou republiku či s celosvětovým záběrem.

Výsledkem tohoto průzkumu bylo zjištění, že diskutovaná kritéria kvality jsou v praxi jen obtížně použitelná. $O$ jejich adekvátnosti současně nepanovala shoda ani mezi členy ohniskové skupiny. Řada kritérií byla velmi specifických a nebylo možné je uplatnit na velkou většinu nalezených případů digitální interpretace, případně se vztahovala pouze k určitému úzkému typu digitální interpretace. To vedlo $\mathrm{k}$ vytvoření nového návrhu (viz Př́loha 3), který se ve větší miŕe opíral o zahraniční literaturu, ale současně integroval i některé postřehy z předchozího procesu ověřování.

Jeho představení bude předmětem následující kapitoly.

\section{Návrh kritérií kvality pro hodnocení terénní digitální interpretace přírodního dědictví}

Navrhovaný hodnotící nástroj (viz Př́loha 3) chápeme jako určitého průvodce, který má vést $\mathrm{k}$ hlubšímu zamyšlení se nad konkrétním produktem digitální interpretace. Každé kritérium je třeba proto chápat jako flexibilní, přizpůsobitelné specifickým požadavkům, cílům a technickému formátu interpretace.

Hodnotící nástroj se skládá ze čtyř základních kategorií:

- Interpretační charakteristiky

- Uživatelská př́ijemnost

- Interakce

- Obsah

Každá z kategorií je dále rozčleněna na čtyři dílčí kritéria, která nabízejí specifický úhel pohledu na hodnocenou interpretaci v rámci dané kategorie.

\section{Interpretační charakteristiky}

Zahrnují klíčová kritéria pro interpretační sílu digitální interpretace. Předpokládáme, že by interpretační produkt měl vycházet z tematického principu. Podle Hama $(1992,2013)$ by interpretace měla komunikovat jedno hlavní sdělení, nastíněné z různých úhlů pohledu. Pro další hodnocení doporučujeme, aby byl zachován význam anglického termínu "theme" jako hlavního sdělení interpretace.

Digitální interpretace by měla být uspořádaná tak, aby bylo jednoduché jí porozumět. Ham $(1992,2013)$ doporučuje, aby interpretační program jako celek nekomunikoval více než 3-5 nových myšlenek, které společně vyjadřují jeho hlavní sdělení. $V$ předkládaném hodnocení nabízíme širší pojetí tohoto uspořádání. Podle Zimmermana a Landa (2014) je 
důležitým aspektem kvality způsob, jakým digitální interpretace pomáhá organizovat porozumění klíčovým konceptům. Součástí kvalitního uspořádání proto může být i otázka posloupnosti prezentovaného obsahu či jeho vizualizace.

Důležitost propojování obsahu s osobností návštěvníka je základem oboru interpretace (Tilden, 1957; Ham, 1992, 2013; Zimmerman \& Land, 2014). V rámci hodnocení je možné se zaměřit na různé typy indikátorů, jako je komunikace univerzálních konceptů, potenciál interpretace navazovat na předpokládané znalosti návštěvníka, či schopnost používat pro komunikaci jeho jazyk.

Propojování s lokalitou je další klíčovou charakteristikou dobré digitální interpretace. Zde je třeba uvést, že digitální interpretace může pracovat se všemi fázemi návštěvnického cyklu, tj. před, při i po návštěvě (Davies, 2014). Kvalitní interpretace by proto ve fázi „při návštěvě" měla být poměrně "skromná", to znamená, že by neměla pohlcovat návštěvníka nad nezbytnou míru. Současně by měla podporovat aktivní zkoumání lokality, nikoli tedy odvádět pozornost ke zkoumání samotné aplikace.

\section{Uživatelská př́ijemnost}

Kategorie se zabývá vlastnostmi digitální interpretace nezbytnými pro udržení zájmu návštěvníka a navrhuje jejich kritéria. Aplikace by měly mít snadné, intuitivní ovládání (Walmsley \& Crowe, 2016). J ejich provoz by současně měl být prost chyb, technických nejasností a složitých postupů, které mohou návštěvníka odradit od jejich používání.

Technické problémy představuji jednu z nejčastějších bariér zmiňovaných návštěvníky i experty. Je zřejmé, že přinejmenším $v$ nejbližší době nelze očekávat, že si návštěvníci budou $v$ prírodních oblastech se špatným pokrytím signálem stahovat veliké objemy dat. Současně ani není z hlediska ochrany prírody žádoucí podporovat budování související infrastruktury. To volá po takovém technickém řešení, které vyžaduje stahování pouze malého množství dat $v$ průběhu návštěvy. Řešením je proto dobré propracování fází před a po návštěvě, případně zpracování obsahu tak, aby mohl být na místě sledován offline.

Kvalitní interpretace by měla být do určité míry zábavná (Walmsley \& Crowe, 2016., Pendit, Zaibon, \& Bakar, 2014; Liarokapis, Sylaiou \& Mountain, 2008). Přestože některé názory expertů je možné chápat jako implicitní obavu z vytlačení cílené komunikace zábavnými aspekty nových technologií, považujeme toto kritérium za důležité pro udržení zájmu návštěvníků o používání aplikace. Současně je zjevné, že by dobrá digitální interpretace měla mezi zábavou a učením udržovat rovnováhu, respektive zábava by neměla být na úkor př́mého zážitku návštěvníka s místem (Beck \& Cable 2011:82).

Vyvážené množství informací znamená, že by se digitální interpretace měla vyvarovat zavalení návštěvníka př́lišným objemem textu či jinak prezentovaných informací (Liarokapis, Sylaiou \& Mountain, 2008). Je zjevné, že vlastnosti digitálního média takový přístup, na rozdíl od interpretace pomocí tištěných materiálů, umožňují. Stejně tak dovolují i vhodně strukturovat obsah a informace prezentovat vícevrstevně. Při posuzování množství obsahu je také vhodné přihlédnout $k$ fázi návštěvnického cyklu (jiné množství informací může být komunikováno při návštěvě a po ní), i k možnostem zaměřit části digitální aplikace pro různé cílové skupiny.

\section{Interakce}

Kategorie se soustředí na specifický rys digitálních médií, který je výrazně odlišuje od dalších prostředků interpretace. Při interakci přestává být návštěvník pasivním příjemcem informací, ale jejich skladbu a množství může ovlivňovat (Veverka 2011), či se stává jejich 
spolutvưrcem. Předpokládáme, že návštěvníci by měli mít možnost aktivně rozhodovat o způsobu své interakce s aplikací (např. volbou různých modů zobrazení obsahu) a mít tak nad ní určitý stupeň kontroly (Pendit, Zaibon \& Bakar, 2014; Shin, Jung \& Chan, 2014.

Aplikace by dále $v$ rozumné míre měla nabízet uživatelům různé úkoly a herní prvky. Tuto "gamifikaci" je třeba chápat dostatečně široce. Je zjevné, že jiné nároky budou kladeny na aplikaci určenou pro žáky a jiné pro dospělé návštěvníky. Zdá se ale, že důležitost určité míry gamifikace má podporu v odborné literatuře (Walmsley \& Crowe, 2016; Zecha, 2012) a Ize předpokládat, že by ji uvítala i část návštěvnické veřejnosti.

Možnost spoluvytvářet obsah může zahrnovat jak prostor pro sdílení svého hodnocení lokality, tak např. prostor pro zasílání fotografií. Význam fotografování pro posílení fascinace prírodou zmiňuje ve svém výzkumu Lindnell (2014).

Analogicky by aplikace měla umožňovat sdílení návštěvnických zážitků a objevů, například v rámci sociálních sítí či digitálních fór navázaných na aplikaci (Zimmerman \& Land, 2014). Je třeba zmínit, že $\mathrm{k}$ této funkci se vztahovala řada pochybností vyjádřená $v$ rámci ohniskové skupiny experty. Je proto důležité nastavit takový mechanismus sdílení, jehož podpora bude pro provozovatele digitální interpretace dlouhodobě udržitelná. Naopak podpora této myšlenky se objevila při návrhu využívat sociální sítě pro sdílení fotografií z interpretačního programu.

\section{Obsah}

Poslední kategorie - „obsah“ - se soustred'uje na způsob využití digitálních médií pro prezentaci informací. Prvním důležitým kritériem je "vrstevnatost" (Liarokapis, Sylaiou, \& Mountain, 2008). Na rozdíl od „pevné“ interpretace (tj. interpretace, která nevyužívá digitální média), u které se doporučuje zpracování obsahu pro co nejširší návštěvnickou skupinu, umožňuje digitální interpretace teoreticky oslovit neomezené spektrum návštěvníků pomocí personalizovaných či specificky zaměřených informací. Návštěvník by se tak měl dostat $k$ takové digitální vrstvě, která koresponduje $\mathrm{s}$ jeho zájmem a odbornou úrovní. V současné době můžeme jako minimální standard chápat vytvoření speciálních vrstev pro cizojazyčné návštěvníky. Další možnost nabízí rozlišení na laickou a expertní informační vrstvu, prípadně na verzi pro dospělé a pro děti. Při hodnocení tohoto kritéria je také třeba zvážit celkový kontext interpretace, kdy jednotlivé vrstvy mohou být neseny různými médii, tj. např́klad informace pro běžnou veřejnost může být komunikována prostřednictvím pevné interpretace, zatímco pro odbornou bude médiem její digitální vrstva.

Multimediálnost předpokládá funkční využití digitálního média - pro prezentování nejenom textových a grafických informací tak může sloužit např́klad video, zvukové nahrávky, animace či aplikace založené na technologiích AR/MR/VR (Pendit, Zaibon \& Bakar, 2014; Walmsley \& Crowe, 2016). Vhodné využití médií může obohatit návštěvníka o nový zážitek z místa a může mu pomoci v porozumění komunikovaného sdělení. Při navrhování nové interpretace je třeba zvážit technické nároky, a podle situace i načasování datově náročných médií do první či poslední fáze návštěvnického cyklu (po návratu z lokality).

Prvek překvapení (Pendit, Zaibon \& Bakar, 2014; Walmsley \& Crowe, 2016) znamená, že je žádoucí zapojit kreativitu tvưrců digitální aplikace. Předpokládáme, že "překvapení nemusí být nutně spojeno s technologicky inovativními postupy. Jeho jádrem je spíše určitá hra s návštěvníkem a snaha oživit intepretaci nečekaným prvkem.

Walmsley a Crowe (2016) dále doporučují zařadit do aplikací praktické informace, jako je digitální mapa s možností zoomování, odkazy na jízdní raády či otevírací hodiny blízkých 
restaurací. Je zřejmé, že dobré zvládnutí tohoto kritéria by zvýšilo atraktivitu digitální aplikace a mohlo tak posílit šanci i na účinnější komunikaci jejího interpretačního obsahu.

\section{Diskuse a závěr}

Prezentovaný návrh kategorií kvality digitální interpretace přináší řadu otázek. První jsou jednotlivá kritéria kvality. Veliká různorodost digitální interpretace nutně vede k situaci, kdy ne všechna kritéria jsou použitelná pro všechny její typy, současně pro některé typy mohou být specifická dílči kritéria velmi důležitá. Do přehledu kritérií kvality je proto teoreticky možné přidat řadu dalších dílčích kritérií (např. využití autentického obsahu), prípadně jiná kritéria odstranit (např. multimediálnost, překvapení).

Druhou otázkou je řazení kritérií do čtyř základních kategorií. Je zřejmé, že zařazení některých kritérií do př́slušné základní kategorie (např. vrstevnatosti do uživatelské př́íjemnosti) je spíše otázkou úhlu pohledu a více řešení je možných.

Konečně otázkou je i samotné pojetí návrhu hodnocení digitální interpretace, založeného na poměrně širokých kategoriích a snažícího se podchytit celou oblast terénní digitální interpretace. Možnou alternativou by mohla být naopak série specificky zaměřených nástrojů $\mathrm{s}$ přesně vymezenými kategoriemi.

Oblast terénní digitální interpretace je v České republice stále ještě velice mladá. Předkládanou studii je proto třeba chápat jako jeden z prvních pokusů o její podchycení. Doufáme, že předložený návrh otevře diskusi, která povede k efektivnímu využití elektronických médií pro interpretaci.

\section{Literatura}

- Beck, L., \& Cable, T. (2011). The Gifts of Interpretation. Urbana: Sagamore publishing.

- Davies, J. (2014). On-site Digital Heritage Interpretation: Current uses and future possibilities at World Heritage Sites. Durham: Durham University.

- Ham, S. H. (2013). Interpretation - making a difference on purpose. Golden: Fulcrum Publishing.

- Ham, S. H. (1992). Environmental interpretation: a practical guide for people with big ideas and small budgets. Colorado: Fulcrum Publishing.

- Liarokapis, F., Sylaiou, S., \& Mountain, D. (2008). Personalizing Virtual and Augmented Reality for Cultural Heritage Indoor and Outdoor Experiences. In The 9th International Symposium on Virtual Reality, Archaeology and Cultural Heritage, VAST (2008), pp.1-8.

- Lindell, S. K. (2014). Reconciling technology and nature: the use of mobile technology in outdoor recreation. Thesis. Western Washington University.

- Pendit, U. C., Zaibon, S. B., \& Bakar, J.A. A. (2014). Mobile Augmented Reality for Enjoyable Informal Learning in Cultural Heritage Site. International J ournal of ComputerApplications, 92(14), 19-26. 
- Shin, D., Jung, J., \& Chang, B. (2014). The psychology behind QR codes: User experience perspective Computers in Human Behavior. Computers in HumanBehavior, 28(4), 1417-1426. https://doi.org/10.1016/j.chb.2012.03.004

- Taggmanager.cz (2017). Naše stezky. Retrieved from http://www.taggmanager.cz/reference

- Tilden, F. (1957). Interpreting our heritage: Principles and Practices for Visitor Services. Chapel Hill: University of North Carolina Press.

- Veverka, J. A. (2011). The interpretative training handbook. Edinburgh: MuseumsEtc.

- Walmsley, J. \& Crowe, L. (2016). What makes a good smartphone app for outdoor recreation? Outdoor recreation network, 27. Retrieved from https://www. outdoorrecreation.org.uk/stories/makes-good-smartphone-app-outdoor-recreation/

- Zecha, S. (2012). Geocaching, a tool to support environmental education!? - An explorative study. Educational Research Journal, 1(2), 177-188.

- Zimmerman, H. T. \& Land, S. M. (2014). Facilitating place-based learning in outdoor informal environments with mobile computers. TechTrends, 58(1), 77-83. 


\section{Přílohy}

\section{Příloha 1 První verze kritérií kvality}

- Pomáhá digitální část komunikovat hlavní sdělení celé naučné stezky?

- Komunikuje digitální část dílči sdělení, korespondující s hlavním sdělením celé naučné stezky?

- Má digitální část jasně vymezenou cílovou skupinu/y?

- Používá digitální část pro komunikaci jazykové prostředky odpovídající její cílové skupině?

- Je přístup do digitální části i její ovládání intuitivní a uživatelsky příjemné pro širokou skupinu uživatelů?

- Umožňuje ovládání vybrat si konkrétní obsah, namísto nutnosti postupovat sekvenčně?

- Je digitální část zpracována takovým způsobem, který umožňuje přístup i před návštěvou či po návštěvě naučné stezky?

- Používá digitální část vícevrstevného přístupu k obsahu?

- Je obsah jasně strukturován v souladu s komunikovanými sděleními?

- Využívá aplikace schémat a grafiky tam, kde je to možné?

- Je grafika jasně propojena s textem?

- Umožňuje digitální část čtení v alespoň jednom cizím jazyce?

- Umožňuje digitální část zpřístupnění obsahu i nevidomým osobám?

- Využívá digitální část takové technické řešení, které je dostupné široké skupině uživatelư?

- Je digitální část plně funkční, tj. bez nefungujících odkazů, částí či jiných technických problémů?

- Komunikuje digitální část informace, které jsou aktuální, v souladu se současným stavem poznání?

- Podporuje digitální část (motivuje, poskytuje podporu) k dalšímu nezávislému získávání informací o lokalitě?

- Motivuje digitální část ke komunikaci návštěvníků s odbornou veřejností a pracovníky odpovědnými za ochranu lokality (např. formou posílání podnětů, dotazů atd.)?

- Propojuje digitální část návštěvníka s širší komunitou?

- Propojuje nebo srovnává digitální část předmět interpretace s každodenním životem lidí nebo sdílenou zkušeností (např. používáním analogií a/nebo metafor)? 
- Obsahuje interpretace autentické materiály, přiběhy či vyprávění založená na skutečných historických událostech a konkrétních postavách?

- Je digitální část jednoznačně propojena s jevy či objekty v nejbližším okolí?

- Vyzývá digitální část návštěvníky k přímému pozorování, bližšímu zkoumání, ochutnávání apod.?

- Je digitální část zpracována takovým způsobem, aby byla minimalizována doba strávená jejím prohlížením bez prímé interakce s okolním prostředím?

- Umožňuje digitální část návštěvníkům podílet se na interpretaci lokality?

- Podporuje komunikovaný obsah hodnoty související s ochranou životního prostředí a dané lokality a povzbuzuje návštěvníky k šetrnému chování?

- Ukazuje digitální část nové perspektivy umožňující lépe rozumět významu lokality a důvody pro její ochranu? 


\section{Příloha 2 Seznam účastníkư ohniskové skupiny}

- Michal Medek, Ústav pro interpretaci místního dědictví ČR (UIMID);

- Mirek Lupač, Agentura Koniklec;

- Ondřej Vítek, Agentura ochrany př́rody a krajiny (AOPK);

- Michal Skalka, Správa Krkonošského národního parku (KRNAP);

- Jan Moravec, Český svaz ochránců př́rody;

- Radek Borovička, Český svaz ochránců př́rody ZO Natura Quo Vadis;

- Milan Maršálek, Český svaz ochránců př́rody ZO Natura Quo Vadis;

- Hana Maršáleková, Český svaz ochránců př́rody ZO Natura Quo Vadis;

- Martina Pásková, Ministerstvo životního prostředí (předsedkyně Rady národních geoparků a členka České komise pro UNESCO);

- Dalibor Kvita, Geopark Podbeskydí;

- Roman Mráz, Národní park Šumava. 


\section{Příloha 3 Finální verze kritérií kvality pro terénní digitální interpre- taci přírodního dědictví}

Přehled kategorií a kritérií kvality digitální interpretace s ilustračními otázkami:

\section{Interpretační charakteristiky}

- Tematický přístup (Komunikuje či pomáhá komunikovat jedno hlavní sdělení o lokalitě? Je hlavní sdělení podporováno vedlejšími sděleními?)

- Uspořádání (Je přehledně a hierarchicky uspořádána? Obsahuje omezený (zvládnutelný) počet nových myšlenek na dané hierarchické úrovni?)

- Propojování s návštěvníkem (Je relevantní pro běžné návštěvníky či dané typy návštěvníků? Používá jejich jazyk? Pracuje s autentickými materiály?)

- Propojování s lokalitou (Propojuje návštěvníka s lokalitou, tj. motivuje ho ke zkoumání okolí?)

\section{Uživatelská příjemnost}

- Snadnost ovládání a funkčnost (Je ovládání srozumitelné a intuitivní?)

- Technická nenáročnost (Nebrání jejímu využití technické bariéry, jako jsou nutnost stahovat zvláštní aplikaci, mimořádné nároky na mobilní zařizení, kvalitu/dostupnost signálu a nutnost stahovat v lokalitě velké množství dat?)

- Zábava (Je zpracovaná tak, že uživatele baví i učí současně?)

- Vyvážené množství informací (Obsahuje zvládnutelné množství informací, nezavaluje návštěvníka přemírou textu atd.?)

\section{I nterakce}

- Kontrola (Mají uživatelé možnost volit si skladbu a množství informací, atd.?)

- Úkoly a gamifikace (Obsahuje úkoly na aktivní hledání v okolí, opakování komunikovaných znalostí či jinou formu hry, která by motivovala k učení?)

- Spoluvytváření obsahu (Umožňuje uživatelům nahrávat vlastní texty, reflexe, fotografie atd.?)

- Sdílení (Umožňuje uživatelům komunikovat a sdílet informace s jinými návštěvníky, uživateli či jinými zainteresovanými stranami?)

\section{Obsah}

- Vrstevnatost (Nabízí různé rozhraní a obsah pro různé skupiny návštěvníků, tj. např. jiné pro odborníky, rodiče, děti atd.?)

- Multimediálnost (Využívá, tam kde je to vhodné, grafiku a multimédia, tj. např. animace, zvukové nahrávky, rozšířenou realitu, atd.?) 
- Překvapení (Obsahuje $v$ přiměřené míře vhodné, ale neočekávané prvky, které mohou uživatele $v$ dobrém slova smyslu překvapit, potěšit a motivovat ke zkoumání lokality?)

- Mapa a praktické informace (Obsahuje, tam kde je to vhodné, praktické informace, které pomohou návštěvníkům zorientovat se $v$ terénu a plánovat další postup lokalitou?). 